\title{
Mycoplasma Genitalium Among Women With Nongonococcal, Nonchlamydial Pelvic Inflammatory Disease
}

\author{
Catherine L. Haggerty, ${ }^{1,2}$ Patricia A. Totten, ${ }^{3}$ Sabina G. Astete, ${ }^{3}$ and Roberta B. Ness ${ }^{1}$ \\ ${ }^{1}$ University of Pittsburgh, Pittsburgh, PA 15260, USA \\ ${ }^{2}$ Department of Epidemiology, University of Pittsburgh, 130 DeSoto Street, 516B Parran Hall Pittsburgh, PA 15261, USA \\ ${ }^{3}$ Department of Medicine, Division of Infectious Diseases, University of Washington, Seattle, WA, USA
}

Received 2 February 2006; Accepted 20 February 2006

\begin{abstract}
Pelvic inflammatory disease (PID) is a frequent condition of young women, often resulting in reproductive morbidity. Although Neisseria gonorrhoeae and/or Chlamydia trachomatis are/is recovered from approximately a third to a half of women with PID, the etiologic agent is often unidentified. We need PCR to test for $M$ genitalium among a pilot sample of 50 women with nongonococcal, nonchlamydial endometritis enrolled in the PID evaluation and clinical health (PEACH) study. All participants had pelvic pain, pelvic organ tenderness, and leukorrhea, mucopurulent cervicitis, or untreated cervicitis. Endometritis was defined as $\geq 5$ surface epithelium neutrophils per $\times 400$ field absent of menstrual endometrium and/or $\geq 2$ stromal plasma cells per $\times 120$ field. We detected $M$ genitalium in 7 (14\%) of the women tested: $6(12 \%)$ in cervical specimens and $4(8 \%)$ in endometrial specimens. We conclude that $M$ genitalium is prevalent in the endometrium of women with nongonococcal, nonchlamydial PID.
\end{abstract}

Copyright (c) 2006 Catherine L. Haggerty et al. This is an open access article distributed under the Creative Commons Attribution License, which permits unrestricted use, distribution, and reproduction in any medium, provided the original work is properly cited.

\section{INTRODUCTION}

Mycoplasma genitalium was first identified in the early 1980s among men with nongonococcal urethritis [1]. M genitalium is extremely difficult to culture, but the use of polymerase chain reaction (PCR) technology has allowed research into the pathogenicity of this organism. Numerous studies have confirmed the role of $M$ genitalium in drug resistant nongonococcal urethritis [2-18], and four relatively recent studies have shown $M$ genitalium to be associated with cervicits [19-22], independent of Chlamydia trachomatis and Neisseria gonorrhoeae [20-22]. Few studies have examined $M$ genitalium among women with pelvic inflammatory disease (PID), the common infection and inflammation of the female upper genital tract which may lead to major reproductive morbidity including infertility, chronic pelvic pain, ectopic pregnancy, and recurrent PID [23]. Whereas serological studies of $M$ genitalium and PID among women have been suggestive but inconclusive [24, 25], PCR studies have associated $M$ genitalium with clinically suspected PID [1926] and acute endometritis [27]. Only one of these studies confirmed the diagnosis of PID histologically [27], and no studies have examined $M$ genitalium among a population of US women with PID.

$C$ trachomatis and/or $N$ gonorrhoeae account for approximately a third to half of PID cases [30, 32-36, 38-50]. Thus, since up to $70 \%$ of PID cases have a largely unidentified etiology, the discovery of new pathogens associated with upper genital tract infection in women would be informative. Anaerobic gram-negative rods and bacterial vaginosis have been associated with PID [30-32, 36-38, 43, 45-50], and we have recently shown this association to be independent of gonococcal and chlamydial infection [51]. It is feasible that $M$ genitalium may also be an etiologic agent in nongonococcal, nonchlamydial PID, as it has been found to induce salpingitis experimentally in monkeys $[52,53]$, has been shown to adhere to human fallopian tube epithelial cells in organ culture [54], and has been detected in fallopian tube tissue in a woman with salpingitis [55]. Further, $M$ genitalium has been shown to adhere to human spermatozoa, and therefore may potentially be carried by motile sperm to the female upper genital tract [56].

\section{SUBJECTS}

We conducted a pilot substudy to determine the prevalence of $M$ genitalium among a sample of urban US women with nongonococcal, nonchlamydial PID using specimens collected as part of the PID evaluation and clinical health $(\mathrm{PEACH})$ study. The methods of PEACH study participant recruitment, data collection, and followup have been 
described in detail elsewhere [57]. Briefly, women aged 14 to 37 years were recruited from emergency departments, OB/GYN clinics, STD clinics, and private practices at thirteen clinical sites located throughout the eastern, southern, and central regions of the US between March 1996 and February 1999. Women with clinically suspected PID who gave informed consent were eligible for the PEACH study. All participants had clinically suspected PID: pelvic, pain, pelvic organ tenderness; and leukorrhea, mucopurulent cervicitis, or untreated cervicitis. Eight hundred thirty one women met all of the inclusion criteria and were enrolled into the PEACH study. Six hundred fifty four women consented to endometrial biopsies. Histologic evidence of endometritis, defined as $\geq 5$ surface epithelium neutrophils per $\times 400$ field absent of menstrual endometrium and/or $\geq 2$ stromal plasma cells per $\times 120$ field, was found among 311 women.

\section{METHODS}

Cervical and endometrial specimens from a sample of 50 women with nongonococcal, nonchlamydial endometritis were tested for $M$ genitalium using the MgPa-IMW PCR assay targeting the $\mathrm{MgPa}$ gene [19]. For all samples testing positive for $M$ genitalium, a second MgPa PCR assay was performed using another aliquot of the sample to rule out PCR product contamination or cross-contamination; all samples initially positive were verified as positive in this confirmatory test. Frequencies and Pearson's correlations were calculated using SAS version 8.2 for Windows.

\section{RESULTS}

We detected $M$ genitalium in 7 (14\%) of the women tested. Twelve percent of cervical specimens and 8 percent of endometrial specimens were positive for $M$ genitalium, and infection at these sites was highly correlated (Pearson's correlation $0.57, p=0.0001$ ), with $75 \%$ of endometrial positive cases also positive at the cervix and $50 \%$ of cervical positive cases also positive in the endometrium. Both plasma cells and neutrophils were identified in 3 (75\%) of the 4 women with endometrial $M$ genitalium compared to 18 (42\%) of 43 women without $M$ genitalium in the endometrium, although these findings were not statistically significant.

\section{DISCUSSION}

We identified $M$ genitalium frequently among an urban US population of women with nongonococcal, nonchlamydial PID. The overall prevalence of $14 \%$ is similar to that found in prior PCR investigations among Kenyan women with histologically confirmed endometritis (16\%) [27] and United Kingdom women with clinically suspected PID (13\%) [26]. In the PEACH study, about $14 \%$ of women were infected with $C$ trachomatis, $15 \%$ were infected with $N$ gonorrhoeae, and $5 \%$ were coinfected [58]. Thus, $M$ genitalium was as prevalent as $C$ trachomatis or $N$ gonorrhoeae among this population of women with PID.
Most women with PID are treated with antibiotics directed toward $N$ gonorrhoeae and/or $C$ trachomatis, despite the fact that these bacterial pathogens account for only a third to half of PID cases. Indeed, in the PEACH study the majority of women, approximately $60 \%$, had nongonococcal, nonchlamydial PID [58]. Over a third of the women in the PEACH study had persistent endometritis at 30 days [58] and over a third experienced chronic pelvic pain subsequent to baseline [59], suggesting that a sizeable portion of women in the PEACH study had ongoing inflammation and infection. Women in the PEACH study were treated with a combination of cefoxitin and doxycycline [58], a PID treatment regimen currently recommended by the centers for disease control and prevention. No studies have examined the efficacy of this or any other treatment regimen among women with $M$ genitalium PID. However, several attributes of $M$ genitalium suggest it is resistant to cefoxitin and doxycycline. First, mycoplasmal bacteria lack a cell wall, and are thus resistant to cell wall inhibiting antibiotics, including penicillin and cephalosporin. Second, $M$ genitalium has been found to persist among men treated with tetracyclines for nongonococcal urethritis [60]. Antibiotic resistance among $M$ genitalium strains may lead to persistent or recurrent infection among women with PID, resulting in chronic inflammation and infection of the lower and upper genital tract. Further studies are needed to determine the efficacy of PID treatment regimens for the eradication of endometrial and tubal $\mathrm{Mgen}$ italium.

Successful treatment of PID is critical for the prevention of subsequent reproductive morbidity. We have previously shown that women in the PEACH study with $N$ gonorrhoeae or $C$ trachomatis identified in the endometrium were not more likely to experience infertility, chronic pelvic pain, or recurrent PID than those negative for each [59]. Further, those who tested positive for nongonococcal bacteria were generally more likely to experience reproductive morbidity than were women with endometrial gonococcal infection (infertility rates were $13 \%$ for $N$ gonorrhoeae, $19 \%$ for C trachomatis, 22\% for anaerobic bacteria, 27\% for $U$ urealyticum, and $17 \%$ for $M$ hominis; chronic pelvic pain rates were $27 \%$ for $N$ gonorrhoeae, $21 \%$ for C trachomatis, 33\% for anaerobic bacteria, $41 \%$ for $U$ urealyticum, and $54 \%$ for $M$ hominis). Thus, women with nongonococcal PID may be at greater risk for adverse outcomes. Few studies have examined reproductive sequelae attributed to $M$ genitalium upper genital tract infection, but $M$ genitalium antibodies have been identified more frequently (22\% versus 6\%) among women with tubal factor infertility compared to women with nontubal factor infertility [61].

Given the frequency of $M$ genitalium among women with PID demonstrated in this report and in those by previous investigators $[19,26,27]$, we recommend that treatment for PID be reevaluated for its effectiveness against nongonococcal, nonchlamydial PID. M genitalium has demonstrated susceptibility to macrolides, with azithromycin being the most active, and variable resistance to fluroquinolones, including ciprofloxacin $[60,62]$. A newer quinolone, moxiflocacin, has recently been shown to exhibit better activity against 
$M$ genitalium [63]. Further study of alternative regimens for the treatment of $M$ genitalium PID and the prevention of adverse reproductive sequelae is needed.

\section{ACKNOWLEDGMENTS}

The principal investigators of the PEACH study include the following: Antonio Amortegui, MD; Susan L. Hendrix, DO; Sharon L. Hillier, PhD; Robert L. Holley, MD; Deborah B. Nelson, PhD; Roberta B. Ness, MD, MPH; John Nichols, Jr., MD; Jeffrey Peipert, MD; Hugh Randall, MD; Diane Schubeck, MD; Steven J. Sondheimer, MD; David E. Soper, MD; Richard L. Sweet, MD; Wayne Trout, MD; Guiliana Trucco, MD; Harold C. Wiesenfeld, MD; and Tamer Yalcinkaya, MD. We thank and acknowledge the efforts of interviewers who recruited and interviewed study participants as follows: Susan Allen, Audrey Baum, Corina Becker, Hope Cohen-Webb, Amy Cooper, Peg Crowner, Leslie Curll, Jackie Faas, Amanda Farmer, Emily Hoffman, Anne Holdredge, Alice Howell, Susan Kay, Faye Leboeuf, Ingrid Macio, Kathy Martin, Margaret McNamee, Ann Meers, Kim Miller, Andrea Montagno, Joy Mowery, Jan Mitton, Cheryl Myers, Brenda Nobels, Tara Pealer, Anne Rideout, Georgia Rothstein, Carol Sams, Tara Schuda, Buffie Schiavoni, Marsha Scott, Kelly Timbers, Sam Whitaker, Lisa Williams, and Mirza Vincetic. We also gratefully acknowledge consultants Tom Songer, $\mathrm{PhD}$; Judy Lave, PhD; and Sheryl Kelsey, PhD; and technical assistants Barbara Kolodziej and Ron Vergona.

\section{REFERENCES}

[1] Tully JG, Taylor-Robinson D, Cole RM, Rose DL. A newly discovered mycoplasma in the human urogenital tract. Lancet. 1981;1(8233):1288-1291.

[2] Carlberg H, Bjornelius E, Jensen JS. Mycoplasma genitaliumthe search for effective treatment. International Journal of STD \& AIDS. 2002:13-30.

[3] Totten PA, Schwartz MA, Sjostrom KE, et al. Association of Mycoplasma genitalium with nongonococcal urethritis in heterosexual men. The Journal of Infectious Diseases. 2001;183(2):269-276.

[4] Maeda S, Tamaki M, Nakano M, Uno M, Deguchi T, Kawada Y. Detection of Mycoplasma genitalium in patients with urethritis. The Journal of Urology. 1998;159(2):405-407.

[5] Jensen JS. Mycoplasma genitalium: a cause of non-gonococcal urethritis? Genitourinary Medicine. 1994;70(5):363.

[6] Taylor-Robinson D, Furr PM, Hanna NF. Microbiological and serological study of non-gonococcal urethritis with special reference to Mycoplasma genitalium. Genitourinary Medicine. 1985;61(5):319-324.

[7] Janier M, Lassau F, Casin I, et al. Male urethritis with and without discharge: a clinical and microbiological study. Sexually Transmitted Diseases. 1995;22(4):244-252.

[8] Mena L, Wang X, Mroczkowski TF, Martin DH. Mycoplasma genitalium infections in asymptomatic men and men with urethritis attending a sexually transmitted diseases clinic in New Orleans. Clinical Infectious Diseases. 2002;35(10):1167-1173.

[9] Horner P, Thomas B, Gilroy CB, Egger M, Taylor-Robinson D. Role of Mycoplasma genitalium and Ureaplasma urealyticum in acute and chronic nongonococcal urethritis. Clinical Infectious Diseases. 2001;32(7):995-1003.
[10] Gambini D, Decleva I, Lupica L, Ghislanzoni M, Cusini M, Alessi E. Mycoplasma genitalium in males with nongonococcal urethritis: prevalence and clinical efficacy of eradication. Sexually Transmitted Diseases. 2000;27(4):226-229.

[11] Horner PJ, Gilroy CB, Thomas BJ, Naidoo RO, TaylorRobinson D. Association of Mycoplasma genitalium with acute non-gonococcal urethritis. Lancet. 1993;342(8871):582-585.

[12] Taylor-Robinson D, Jensen JS, Fehler G, Radebe F, Ballard RC. Observations on the microbiology of urethritis in black South African men. International Journal of STD \& AIDS. 2002;13(5):323-325.

[13] Horner PJ, Thomas B, Gilroy CB, Egger M, Taylor-Robinson D. Do all men attending departments of genitourinary medicine need to be screened for non-gonococcal urethritis? International Journal of STD \& AIDS. 2002;13:667-673.

[14] Morency P, Dubois MJ, Gresenguet G, et al. Aetiology of urethral discharge in Bangui, Central African Republic. Sexually Transmitted Infections. 2001;77(2):125-129.

[15] Keane FE, Thomas BJ, Gilroy CB, Renton A, Taylor-Robinson D. The association of Chlamydia trachomatis and Mycoplasma genitalium with non-gonococcal urethritis: observations on heterosexual men and their female partners. International Journal of STD \& AIDS. 2000;11(7):435-439.

[16] Bjornelius E, Lidbrink P, Jensen JS. Mycoplasma genitalium in non-gonococcal urethritis-a study in Swedish male STD patients. International Journal of STD \& AIDS. 2000;11(5):292296.

[17] Johannisson G, Enstrom Y, Lowhagen G, et al. Occurrence and treatment of Mycoplasma genitalium in patients visiting STD clinics in Sweden. International Journal of STD \& AIDS. 2000;11(5):324-326.

[18] Busolo F, Camposampiero D, Bordignon G, Bertollo G. Detection of Mycoplasma genitalium and Chlamydia trachomatis DNAs in male patients with urethritis using the polymerase chain reaction. The New Microbiologica. 1997;20(4):325-332.

[19] Uno M, Deguchi T, Komeda H, et al. Mycoplasma genitalium in the cervices of Japanese women. Sexually Transmitted Diseases. 1997;24(5):284-286.

[20] Manhart LE, Critchlow CW, Holmes KK, et al. Mucopurulent cervicitis and Mycoplasma genitalium. The Journal of Infectious Diseases. 2003;187(4):650-657.

[21] Falk L, Fredlund H, Jensen JS. Signs and symptoms of urethritis and cervicitis among women with or without Mycoplasma genitalium or Chlamydia trachomatis infection. Sexually Transmitted Infections. 2005;81:73-78.

[22] Pepin J, Labbe AC, Khonde N, et al. Mycoplasma genitalium: an organism commonly associated with cervicitis among west African sex workers. Sexually Transmitted Infections. 2005; 81(1):67-72.

[23] Westrom L. Effect of acute pelvic inflammatory disease on fertility. American Journal of Obstetrics \& Gynecology. 1975; 121(5):707-713.

[24] Moller BR, Taylor-Robinson D, Furr PM. Serological evidence implicating Mycoplasma genitalium in pelvic inflammatory disease. Lancet. 1984;1(8386):1102-1103.

[25] Lind K, Kristensen GB. Significance of antibodies to $M y$ coplasma genitalium in salpingitis. European Journal of Clinical Microbiology. 1987;6(2):205-207.

[26] Simms I, Eastick K, Mallinson H, et al. Associations between Mycoplasma genitalium, Chlamydia trachomatis, and pelvic inflammatory disease. Sexually Transmitted Infections. 2003;79(2):154-156. 
[27] Cohen CR, Manhart LE, Bukusi EA, et al. Association between Mycoplasma genitalium and acute endometritis. Lancet. 2002;359(9308):765-766.

[28] Ness RB, Hillier SL, Richter HE, et al. Douching in relation to bacterial vaginosis, lactobacilli, and facultative bacteria in the vagina. Obstetrics \& Gynecology. 2002;100(4):765.

[29] Simms I, Mallinson H, Peeling RW, et al. Risk factors associated with pelvic inflammatory disease: a UK study. International Journal of STD \& AIDS. 2002;13:18.

[30] Hillier SL, Kiviat NB, Hawes SE, et al. Role of bacterial vaginosis-associated microorganisms in endometritis. American Journal of Obstetrics \& Gynecology. 1996;175(2):435-441.

[31] Kiviat NB, Wolner-Hanssen P, Eschenbach DA, et al. Endometrial histopathology in patients with culture-proved upper genital tract infection and laparoscopically diagnosed acute salpingitis. The American Journal of Surgical Pathology. 1990;14(2):167-175.

[32] Crombleholme WR, Schachter J, Ohm-Smith M, Luft J, Whidden R, Sweet RL. Efficacy of single-agent therapy for the treatment of acute pelvic inflammatory disease with ciprofloxacin. The American Journal of Medicine. 1989;87(5A):142S$147 \mathrm{~S}$.

[33] Monif GR, Welkos SL, Baer H, Thompson RJ. Cul-de-sac isolates from patients with endometritis-salpingitis-peritonitis and gonococcal endocervicitis. American Journal of Obstetrics \& Gynecology. 1976;126(2):158-161.

[34] Sweet RL, Draper DL, Schachter J, Hadley WK, Brooks GF. Microbiology and pathogenesis of acute salpingitis as determined by laparoscopy: what is the appropriate site to sample? American Journal of Obstetrics \& Gynecology. 1980;138(7 pt 2):985989.

[35] Thompson SE III, Hager WD, Wong KH, et al. The microbiology and therapy of acute pelvic inflammatory disease in hospitalized patients. American Journal of Obstetrics \& Gynecology. 1980;136(2):179-186.

[36] Sweet RL, Mills J, Hadley KW, et al. Use of laparoscopy to determine the microbiologic etiology of acute salpingitis. American Journal of Obstetrics \& Gynecology. 1979;134(1):6874.

[37] Kiviat NB, Wolner-Hanssen P, Peterson M, et al. Localization of Chlamydia trachomatis infection by direct immunofluorescence and culture in pelvic inflammatory disease. American Journal of Obstetrics \& Gynecology. 1986;154(4):865-873.

[38] Eschenbach DA, Buchanan TM, Pollock HM, et al. Polymicrobial etiology of acute pelvic inflammatory disease. The New England Journal of Medicine. 1975;293(4):166-171.

[39] Brunham RC, Binns B, Guijon F, et al. Etiology and outcome of acute pelvic inflammatory disease. The Journal of Infectious Disease. 1988;158(3):510-517.

[40] Heinonen PK, Teisala K, Punnonen R, Miettinen A, Lehtinen $\mathrm{M}$, Paavonen J. Anatomic sites of upper genital tract infection. Obstetrics \& Gynecology. 1985;66(3):384-390.

[41] Cunningham FG, Hauth JC, Gilstrap LC, Herbert WN, Kappus SS. The bacterial pathogenesis of acute pelvic inflammatory disease. Obstetrics \& Gynecology. 1978;52(2):161-164.

[42] Lip J, Burgoyne X. Cervical and peritoneal bacterial flora associated with salpingitis. Obstetrics \& Gynecology. 1966;28(4):561-563.

[43] Soper DE, Brockwell NJ, Dalton HP, Johnson D. Observations concerning the microbial etiology of acute salpingitis. American Journal of Obstetrics \& Gynecology. 1994;170(4):10081014; discussion 1014-1017.

[44] Wasserheit JN, Bell TA, Kiviat NB, et al. Microbial causes of proven pelvic inflammatory disease and efficacy of clin- damycin and tobramycin. Annals of Internal Medicine. 1986; 104(2):187-193.

[45] Paavonen J, Teisala K, Heinonen PK, et al. Microbiological and histopathological findings in acute pelvic inflammatory disease. British Journal of Obstetrics \& Gynaecology. 1987;94(5):454-460.

[46] Hong S, Xin C, Qianhong Y, et al. Pelvic inflammatory disease in the People's Republic of China: aetiology and management. International Journal of STD \& AIDS. 2002;13(8):568-572.

[47] Peipert JF, Montagno AB, Cooper AS, Sung CJ. Bacterial vaginosis as a risk factor for upper genital tract infection. American Journal of Obstetrics \& Gynecology. 1997;177:1184-1187.

[48] Gogate A. Mycoplasmal pelvic inflammatory disease. In: Stanek G, Cassell GH, Tully JG, Whitcomb RF, eds. Recent Advances in Mycoplasmology. Proceedings of the 7th Congress of the International Organization for Mycoplasmology; June 1988; Baden near Vienna, Austria. 239-241.

[49] Korn AP, Bolan G, Padian N, Ohm-Smith M, Schachter J, Landers DV. Plasma cell endometritis in women with symptomatic bacterial vaginosis. Obstetrics \& Gynecology. 1995; 85(3):387-390.

[50] Eschenbach DA, Hillier S, Critchlow C, Stevens C, DeRouen T, Holmes KK. Diagnosis and clinical manifestations of bacterial vaginosis. American Journal of Obstetrics \& Gynecology. 1988;158(4):819-828.

[51] Haggerty CL, Hillier SL, Bass DC, Ness RB. Bacterial vaginosis and anaerobic bacteria are associated with endometritis. Clinical Infectious Diseases. 2004;39(7):990-995.

[52] Moller BR, Taylor-Robinson D, Furr PM, Freundt EA. Acute upper genital-tract disease in female monkeys provoked experimentally by Mycoplasma genitalium. British Journal of Experimental Pathology. 1985;66(4):417-426.

[53] Taylor-Robinson D, Furr PM, Tully JG, Barile MF, Moller BR. Animal models of Mycoplasma genitalium urogenital infection. Israel Journal of Medical Sciences. 1987;23(6):561-564.

[54] Collier AM, Carson JL, Hu PC, Hu SS, Huang CH, Barile MF. Attachment of Mycoplasma genitalium to the ciliated epithelium of human Fallopian tubes. In: Stanek G, Cassell GH, Tully JG, Whitcomb RF, eds. Recent Advances in Mycoplasmology. Proceedings of the 7th Congress of the International Organization for Mycoplasmology; June 1988; Baden near Vienna, Austria. 730-732.

[55] Cohen CR, Mugo NR, Astete SG, et al. Detection of $M y$ coplasma genitalium in women with laparoscopically diagnosed acute salpingitis. Sexually Transmitted Infections. 2005; 81(6):463-466.

[56] Svenstrup HF, Fedder J, Abraham-Peskir J, Birkelund S, Christiansen G. Mycoplasma genitalium attaches to human spermatozoa. Human Reproduction. 2003;18(10):2103-2109.

[57] Ness RB, Soper DE, Peipert J, et al. Design of the PID evaluation and clinical health (PEACH) study. Controlled Clinical Trials. 1998;19(5):499-514.

[58] Ness RB, Soper DE, Holley RL, et al. Effectiveness of inpatient and outpatient treatment strategies for women with pelvic inflammatory disease: results from the Pelvic Inflammatory Disease Evaluation and Clinical Health (PEACH) randomized trial. American Journal of Obstetrics \& Gynecology. 2002;186(5):929-937.

[59] Haggerty CL, Ness RB, Amortegui A, et al. Endometritis does not predict reproductive morbidity after pelvic inflammatory disease. American Journal of Obstetrics \& Gynecology. 2003;188(1):141-148.

[60] Taylor-Robinson D. Mycoplasma genitalium - an up-date. International Journal of STD \& AIDS. 2002;13(3):145-151. 
[61] Clausen HF, Fedder J, Drasbek M, et al. Serological investigation of Mycoplasma genitalium in infertile women. Human Reproduction. 2001;16(9):1866-1874.

[62] Hannan PCT. Comparative susceptibilities of various AIDSassociated and human urogenital tract mycoplasmas and strains of Mycoplasma pneumoniae to 10 classes of antimicrobial agent in vitro. Journal of Medical Microbiology. 1998; 47(12):1115-1122.

[63] Hamasuna R, Osada Y, Jensen JS. New antibiotic susceptibility test of Mycoplasma genitalium by using Real-Time PCR. In: Program and Book of Abstracts, 16th Biennial Meeting of the International Society for Sexually Transmitted Diseases Research (ISSTDR); July 2005; Amsterdam, The Netherlands. 303. 


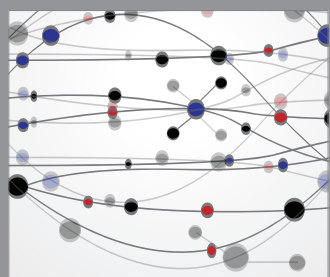

The Scientific World Journal
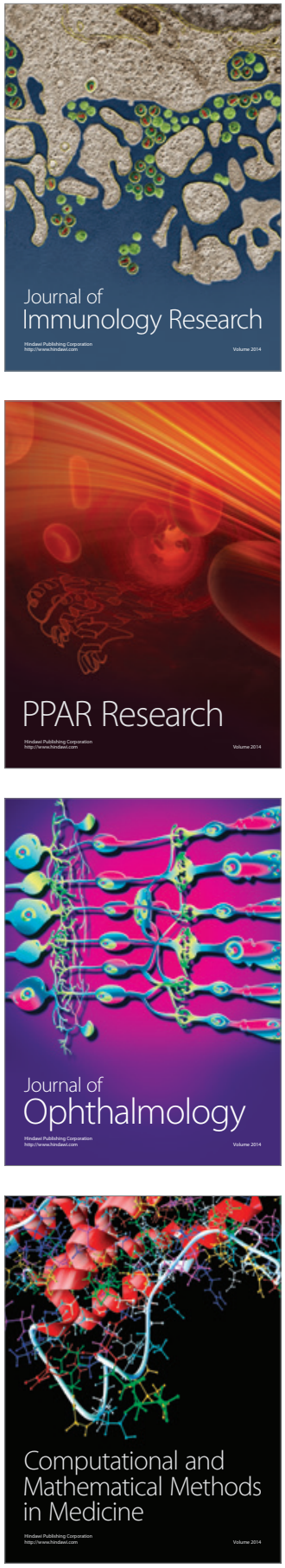

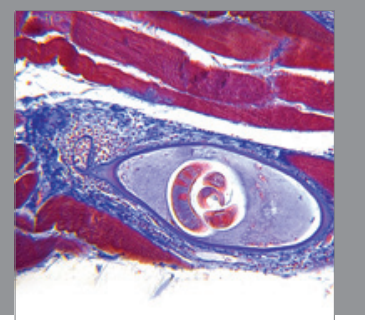

Gastroenterology

Research and Practice
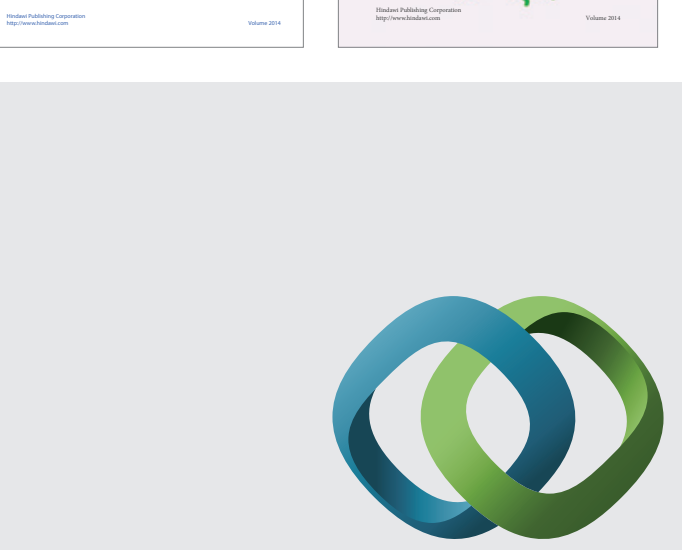

\section{Hindawi}

Submit your manuscripts at

http://www.hindawi.com
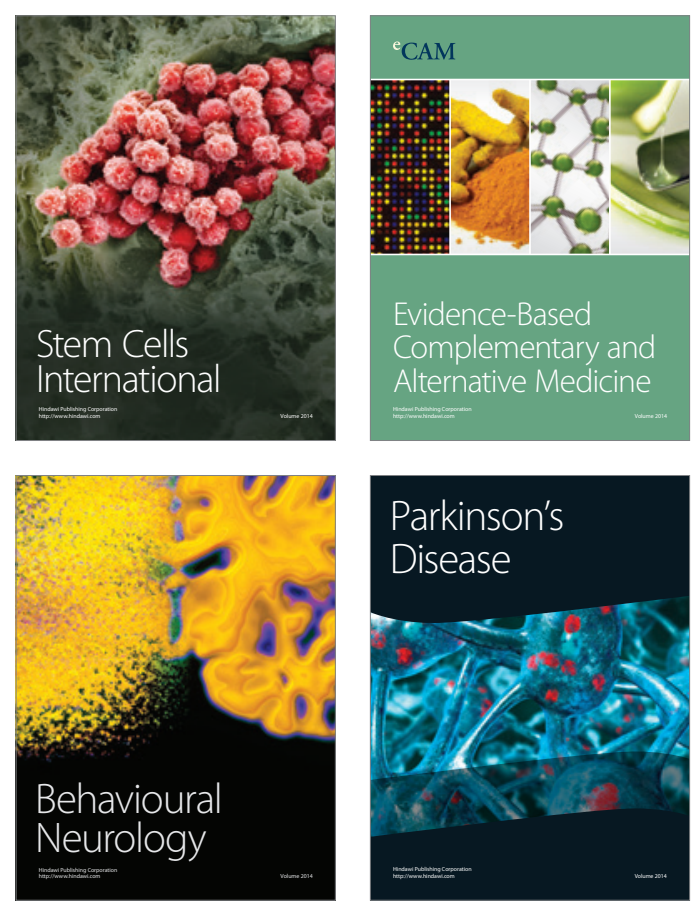

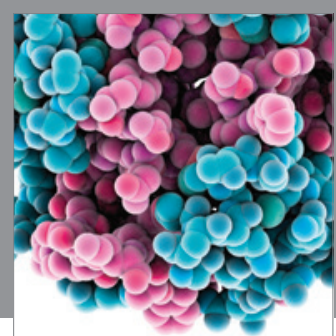

Journal of
Diabetes Research

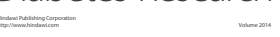

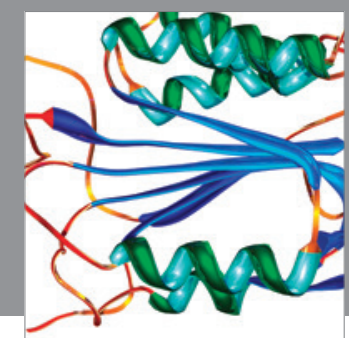

Disease Markers
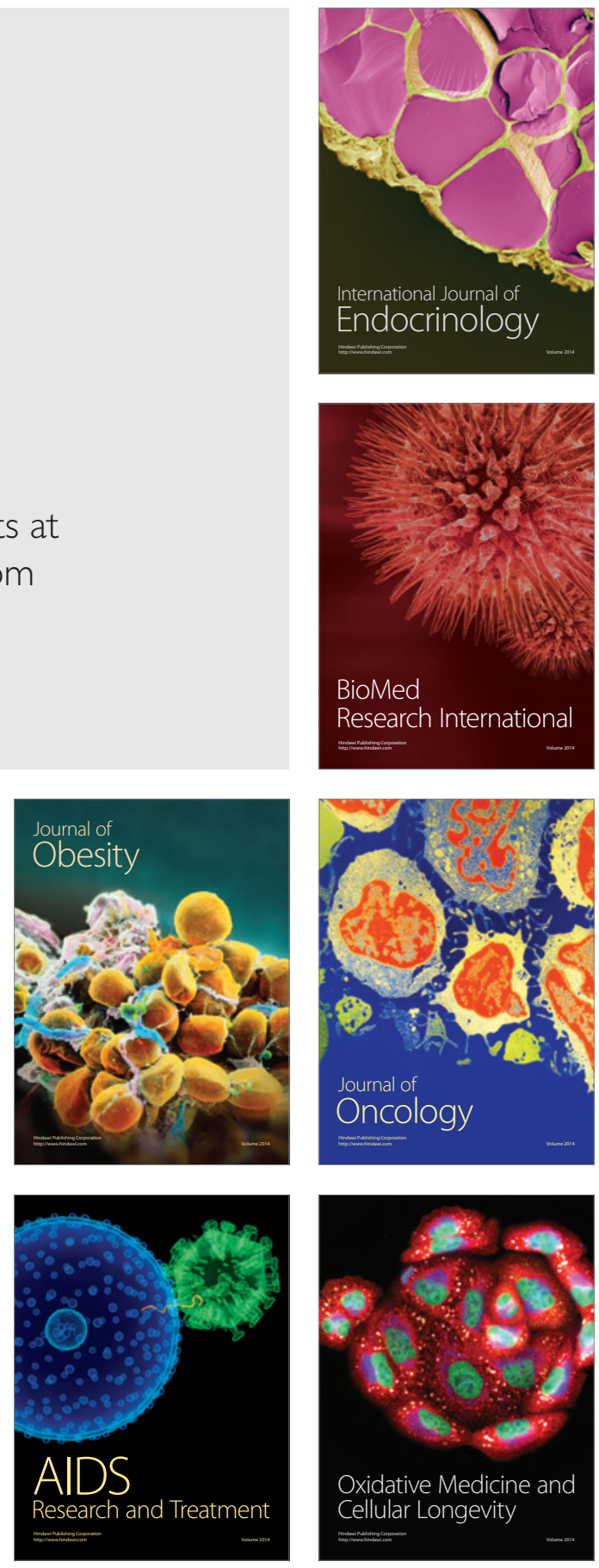